\title{
Analysis on Formation of the Design Philosophy of Le Corbusier
}

\author{
Danting Sun \\ School of Art and Design \\ Wuhan University of Technology \\ Wuhan, China 430070 \\ Fine Arts Academy \\ Yuxi Normal University \\ Yuxi, China 653100
}

\begin{abstract}
The French Architect Le Corbusier was one of the most important architects in the Twentieth Century. He was the radical and main designer of the modern architecture movement. He was known as "the flag bearer of modern architecture". His architectural design works and design concept have far-reaching influence on the development of modern architecture. This paper analyzes the architectural design ideas of Le Corbusier by analyzing his learning experience and the architects who have influenced Le Corbusier in design style.
\end{abstract}

Keywords-Le Corbusier; influence characters; design philosophy

\section{INTRODUCTION}

Le Corbusier (1887-1965), originally named Charles Edouard Jeannert-Gris, was born in La Chaux-de-Fonds in the Swiss Jura Mountains which is not far from the French border. The townspeople mostly make a living from watch-making industry. Cobb's father was a watchmaker, and his mother was a musician. He entered the senior technical and art school which is set up for mounting watchcase in La Chaux-de-Fonds at the age of 14 . Under the guidance of his initiatory teacher Charles L'Eplattenier, he headed for the road of architectural design. Compared with other architects, Le Corbusier's learning experience was extraordinary. Cobb did not receive the special study of the architecture. The architectural education he received was both complex and extensive. He had very strong self-study ability. In the continuous practice and grand tour, he studied classical architecture, learned from outstanding architects, and finally formed his own unique design style.

\section{THE MAIN CHARACTERS WHO INFLUENCED CORBUSIER'S DESIGN PHILOSOPHY}

\section{A. Charles L'eplattenier (1874-1946)}

In 1905, Corbusier was a student of Professor Charles L'Eplattenier, the principal of the arts and crafts school in La Chaux-de-Fonds, who had a great influence on the young Cobb. Cobb described his enlightened teacher as "a mentor who opened the door of my life to the world of art, and together with him to make me indulge in art, as if I lost myself". L'Eplattenier had ever received education and training in the Buza Academy of Fine Arts and the Institute of Decoration Art in Budapest and Paris, upholding the craftsmanship concept of Ruskin and Maurice. He combined the decorative principles of Erwin Jones in his classes, with the tendency of the new art movement. In study, Cobb's many themes of painting were trees, rocks and scenery, and gradually evolved into abstract patterns. From teacher L'Eplattenier, Corbusier learned the ability to extract the structure of things he saw. [1]

In 1906, Cobb, as a good student, designed a house for a member of the board of governors in the art school. The house was slightly younger than the brilliant design of Cobb, but it provided the first travel expenses for Cobb. In 1907, according to the route designated by L'Eplattenier, Cobb began to travel to Italy to study. During the three years, Cobb went to practice as he traveled to study. He went to Italy, France and Germany, leaving a lot of colorful decorative sketches and sketches of architectural appearance. It can be said that it was L'Eplattenier who led Cobb to the road of architecture.

\section{B. Auguste Perret (1874 - 1954)}

Auguste Perret, from a craftsman family, was born with a great understanding of materials. In 1981, Perret entered the Paris Academy of Fine Arts to study architecture. He studies architecture with Julien Guadet. His younger brother Gustave was also in the school, and was excellent in achievements. When the concrete was first popularized in France, Perret felt it would be a great material if the concrete could be used well. Then, in 1897, Perret left the school without a diploma, joined his father's construction company, and set up a Perret brothers design firm with his brother Gustave, exploring the technology of reinforced concrete and engaged in various industrial and civil buildings. After that, they integrated design and construction into one, creating a series of landmark works for future generations.

Perret, under the guidance of Guadet in the Academy of Fine Arts, mainly studied classical architecture, so what he tried to do was to use the concrete structure to build a residential building plane, while maintaining the scale and proportion of the classical architecture. In the summer of 1909 , 
Cob found a job in Berry brothers firm during his travels. He helped Perret make such an attempt. [2]Although he worked only a few months at Perret's firm, Cobb learned how to use a wooden frame to think about the concrete orthogonal frame structure, and learned the rationalistic attitude in the architectural design. In addition, the rationalistic mode of thinking led Cobb to reconsider ancient architecture with a fresh look.

\section{Peter Behrens (1868 - 1940)}

Peter Behrens studied painting at an early age and began to undertake building design at the age of 30. In 1903, he was appointed as dean of Duesseldorf Academy of Fine Arts by Muthesius, and was the principal designer of the German Industrial Alliance. In 1907, the Deutsche Industrial Alliance was established. Behrens served as an art consultant for the $\mathrm{Ge}$ Corp to guide all the activities involved in AEG, from graphic design to product design.

In the spring of 1910, Cobb, with the help of L'Eplattenier, got the job of compiling a monograph on German decoration art. To collect information, Cobb left for Germany to visit colleges, factories and workshops to meet the elites in the German architecture industry. In June 1910, Cobb attended the German Industrial Alliance's meeting in Berlin, met the architect Peter Behrens and visited the newly completed AEG building. [3] By working hard, he entered into Behrens's office for practice in November of the same year. Cobb worked in Behrens's studio for 5 months. He received strict architectural training and gained a new perspective for architectural design. The highly efficient technical organization of Behrens's office also impressed Corbusier deeply. At the same time, Cobb worked with Grospius and Mies van der Rohe, who had entered Behrens's office for a few years, and completed the modernist ideology. The work of the three men in the office had laid a foundation for their future development and was of great significance to their future career. At the end of 1910, Cobb left the Behrens's office. Cobb left Germany in the summer of 1911. He travelled Balkans, Turkey, Greece and Italy, and began to explore the new world of formal beauty. In 1911, he ended "travel to the East" and returned and settled in La Chaux-de-Fonds.

\section{AmÉDÉE Ozenfant (1886 - 1966)}

When Corbusier returned to Switzerland, he taught decorative arts and interior design at the art school while engaged in architectural design. Before the First World War, he designed two houses and a plan, including neoclassical style and Mediterranean classical style. During the First World War, Cobb designed Schwab villa and Skala cinema. But because of the serious overspending of the villa budget and the technical problems of the cinema, Cobb fell into a complex case.

In 1917, Cobb said goodbye to his hometown and moved to Paris. Perret introduced Corbusier to the painter Amédée Ozenfant who gave Corbusier edification when he entered Paris, and was also a collaborator. As early as 1915, it was a period of Cubism. Ozenfant founded the magazine L'Elan, and in an article entitled Notes on Cubism in 1916, cubism was explained to be "a movement of purism". Through Ozenfant, Cobb began to be familiar with Cubist painting, and also encouraged by Ozenfant, Cobb began to take up the brush to paint. They wrote Post-cubism in collaboration for the first purism painting exhibition and it became a manifesto of purism. In the purist painting, there is no portrait or scenery, and most of the paintings are familiar daily necessities, which are sublimated into a general symbol and a form of "plastic" with spiritual character by deformation. They together founded the magazine New Spirit, and mentioned: "a piece of art should draw forth a sense of mathematical order, and the means to bring out this mathematical order should be sought by universal means". [4] Purism emphasizes the accuracy of the outline, the clarity of the lines, the reproduction of the volume, and the general order of the object and the outline, which can be applied directly to the architectural design. Therefore, purism constitutes the core of Corbusier's development of design theory. In Corbusier's works, the embodiment of purism can be seen many times.

\section{LE CORBUSIER'S ARCHITECTURAL DESIGN IDEA}

In Corbusier's career, there were more than a hundred architectural design works and many representative works. The most well-known architectural designs are the Pilgrimage Chapel of Notre Dame du Haut at Ron-champ, the Villa Savoye, Sainte Marie de La Tourette, Marseilles Apartment, the Villas La Roche-Jeanneret, the Quartiers Modernes Fruges and Apartment Block 24 N.C. at Laugese Gauley Street, and the planning design is buildings in Ahmedabad, India. Le Corbusie's architectural idea can be divided into two stages: before 1950s, he was a major representative of functionalism, and representative works were the Villa Sovoye designed in 1929 and Marseilles Apartment designed in 1945. A large number of load-bearing walls were replaced by reinforced concrete in the architectural structure, and the buildings were often emptied above the ground. After 1950s, he turned to expressionism and postmodernism. The Pilgrimage Chapel of Notre Dame du Haut became a representative work of Corbusier with its expressive sense of sculpture and unique form, completely deviating from his early classical style. It is quite extraordinary and has shocked the architectural world.

\section{A. Machine Aesthetics}

During travel to the East, Cobb's concepts of purism built from the architecture of Rome and Cubism from painting have greatly inspired Cobb to change volume into the volume of pure abstract geometry. In 1922, Corbusier collected articles from New Spirit into a book, named Vers Une Architecture, and proposed that we should learn from industrial product manufacture in architecture, apply industrialized methods to reduce construct cost and housing components and construct buildings in a large scale. At the same time, we should see the poetic metaphor of "housing is a machine of living". It is not a purely functionism view, but a beautiful thing to respond to the demand. It is a way of considering building way of dwelling from the perspective of caring for people. Housing is built for people. Except for its functional needs, it also includes consideration of human behavior and lifestyle. Therefore, Corbusier thought that Parthenon had the highest aesthetic spirit, and all modern industrial products are the closest to industrial aesthetics and avant-garde aesthetics in the reality of 
the times, and the combination of the two can truly embody the purpose of architectural design.

\section{B. The Five Principles of Architecture}

2020s was the peak of Corbusier's small house design. Corbusier started his modern residential design tour with Ozenfant's residence. In 1923, he made a figure in the industry with Laroche's housing design. From 1925 to 1927, he completed designs of the new spiritual pavilion, Cook residence, Meyer residence scheme, Stein residence and so on in his high-density production which was modern house designs of a highly speculative spirit. In the process of continuous summing up experience, Cobb insisted on the purity and continuity of design idea, put forward the design concept of "five principles of architecture", and vividly demonstrated the idea in design of Villas Savoye. Villas Savoye has also become the peak of Corbusier's housing design.

The five principles of architecture are building on stilts, horizontal long ribbon-shaped window, free plane, free vertical facade and roof garden. Building on stilts means to support the whole building with a series of pillars, and the wall no longer has the load-bearing function. The bottom is no longer the original entity structure, but is transformed into a column network structure, which can be built to place the entrance of the building and the garage and other auxiliary functional space. As the wall is no longer bearing load, it leads to the following principles. The column network structure makes the partition and vertical wall of the building completely free, which makes it possible to open the long ribbon-shaped window in the horizontal direction. At the same time, there is a larger creative space on vertical facade of building. Cobb used curved staircases and twisty ramps, so that functional architectural components are equally expressive. He dug up the interior walls of the building, enabling free exchange of interior and exterior spaces, thus created a free plane. In order to improve people's living environment and bring people aesthetic experience close to the nature, Cobb's five principles also include roof garden. On the top floor of building sets green space, so that owners can maximize the enjoyment of sunlight and air. This approach has a great impact on modern architecture. To this day, the so-called green building, house garden and the introduction of natural landscapes to building are all based on Cobb's view.

\section{The Utopian Feelings of "Glorious City"}

During the Second World War, the stagnation of building production resulted that Cobb had not engaged in actual building for nearly ten years, so he spent a lot of time on the research of city and modular system, and the Marseilles Apartment was the result of the twenty years of research. It not only reflected the ideal model of Cobb's glorious city, but also integrated his modular system. It also entrusted his utopian social philosophy.

When we study Corbusier's architecture, we shall put it in a macro perspective of a city. As a combination element of the glorious city, Marseilles Apartment can be arranged and spread out in matrix. Because of the technical support of building on stilts, it cannot be restricted by the terrain conditions, such as roads, streams and hills. As a high-rise residential community, he liberated a large number of land, shortened the cost of traffic. All kinds of water and electricity are integrated, and thus reduce costs. The nature is extended to every building from the countryside, which provides a reorganized recreation space for the residents and provides a large number of green plants to produce oxygen. The implantation of air commercial streets and rooftop activity space help people save consumption and entertainment time, for they are not affected by the seasons. These are undoubtedly successful from a functionalist point of view.

A series of congregate houses, represented by Marseilles Apartment, are parts and elements of Cobb's glorious city. On the one hand, the design is based on the physical health of people. The most basic comfort is conceived from the factors of lighting, ventilation, heat insulation and so on. On the other hand, it is from the sociality of human being, from community life and exchange platform and other elements. Finally, include all factors in the huge building like Marseilles Apartment. This idea attempts to meet self-contained material and social needs in a single building, which is very close to the ideal commune model of Fourier and Irving.

\section{Brutalism}

After designing the Villas Savoye, Corbusier's design style began to change, and the Pilgrimage Chapel of Notre Dame du Haut was work in the Cobb's turning from cubism to plastic architecture. After World War II, Cobb became acquainted with Sculptor Savina, and Cobb's artistic creation gradually expanded from two-dimensional image to three-dimensional sculpture. The Pilgrimage Chapel of Notre Dame du Haut can be seen as a magnified-version sculpture of Corbusier. It attracts visitors with its beautiful plastic form, curved and concave-convex walls, undulating black concrete roof and white concrete wall material. This kind of plastic building, represented by the Pilgrimage Chapel of Notre Dame du Haut, keeps the natural color on the material. The texture of concrete has been turned from smooth and delicate to coarse and thick. It embodies the granular sense of the building material and emphasizes the modeling features of the sculpture. It is called "brutalism" architecture. Brutalism was originally proposed by British Smithsons in 1954. On the premise of Corbusier's works, it mainly embodies architecture itself, same as purism, and is particular about the formal beauty of architecture. [5] The brutalism architecture works of Cobb have integrated into his architectural ideas, concepts and architectural techniques, and became classics for architects of later generations to imitate. Corbusier's design thought has affected Europe, America and Asia, including Britain, France, Germany, the United States, Japan, India and other countries. It is the most far-reaching especially in Japan. Maekawa Kunio, Kenzo Tange, Tadao Ando and Japanese designers of other generations continue to follow the footsteps of Cobb, and develop concrete, the plastic building material, to the extreme.

\section{CONCLUSION}

In summary, Corbusier completed an important part of the development of classical architecture to modern architecture. Many architectural forms he has created have become the 
standard architectural form of modernist architecture. His design philosophy has influenced several generations of architects in various countries of the world. Until today, the various buildings around us are still built under the structure created by Corbusier.

\section{REFERENCES}

[1] [American] H.F. Mulgrave. History of Modern Architecture from 1673 to 1968. Translated by Chen Ping, Beijing: Peking University Press, 2017, Page 331. [美]H.F.马尔格雷夫: 《现代建筑理论的历史 16731968》[M], 陈平译, 北京: 北京大学出版社, 2017, 第331页。

[2] Curtis, William J.R. Le Corbusier: Ideas and Forms. Oxford: Phaidon Press Limited, C. 1986: 26.

[3] [American] H.F. Mulgrave. History of Modern Architecture from 1673 to 1968. Translated by Chen Ping, Beijing: Peking University Press, 2017, Page 332. [美]H.F.马尔格雷夫: 《现代建筑理论的历史 16731968》[M], 陈平译, 北京: 北京大学出版社, 2017, 第 332 页。

[4] Charles Harrison. Art in Theory 1900-1990: An Anthology of Changing Ideas. Hoboken: Wiley-Blackwell, 1993: 238.

[5] Jing Qimin, Zhang Li'an: Le Corbusier. Wuhan: Huazhong University of Science and Technology Press, 2012, Page 125. 荆其敏、张丽安: 勒.柯布西耶 $[M]$, 武汉: 华中科技大学出版社, 2012, 第 125 页. 